\title{
New psychoactive substances: reducing the harm caused by untested drugs and an unregulated market
}

\author{
The phenomenon of these substances developed because of the failure of \\ drug prohibition
}

\section{Alex D Wodak FRACP, FAChAM, FAFPHM Emeritus Consultant \\ Alcohol and Drug Service, St Vincent's Hospital, Sydney, NSW. \\ alex.wodak@gmail.com}

doi: 10.5694/mjal4.01138 ew psychoactive substances are so diverse that they cannot be controlled by international law. Many countries, including Australia, have experienced considerable difficulty responding to the steadily increasing number of new psychoactive substances arriving on the black market. In the European Union, 41 new substances were identified in 2010, 49 in 2011 and 73 in 2012. ${ }^{1}$ Over 200 new psychoactive substances have been identified in the European Union since 2005. ${ }^{1}$ The number of new psychoactive substances available in Australia, prevalence of current use and harms caused by these drugs are not known. ${ }^{2}$

Countries race to identify and ban new substances even though this is expensive and ultimately futile. As soon as one new psychoactive substance is banned, the next appears. While demand for psychoactive substances remains strong, there will always be a supply. Globalisation, the internet and social media have increased the already considerable difficulty of interrupting supply of these drugs in the face of continuing strong demand. But the development of these new psychoactive drugs is a direct consequence of the prohibition of other drugs.

The Psychoactive Substances Bill, passed by the New Zealand Parliament on 11 July 2013, aimed to "protect New Zealanders, particularly young New Zealanders, from the harm caused by untested drugs and an unregulated market". ${ }^{3}$ This protection was to be achieved by ensuring that "No one will be allowed to sell psychoactive products unless it can be shown that those products pose no more than a low risk of harm". ${ }^{3}$ The Bill represents the first time in over half a century of global drug prohibition that any country has attempted to regulate psychoactive substances. ${ }^{4}$

During the short time the Bill was in operation, the number of new psychoactive substances available in New Zealand declined by $75 \%$, from an estimated 200 untested drugs to fewer than 50 tested drugs, while availability fell from an estimated 3000 unlicensed outlets to 170 licensed ones. ${ }^{5}$ Drug manufacturers paid a fee and provided information to an expert committee about the structure of their drug. The drugs were then tested. All applications were lodged on a website and interim licences were granted to retail, import, manufacture, wholesale, research and sell unapproved psychoactive products (http:// www.health.govt.nz/our-work/regulation-health-anddisability-system/psychoactive-substances-regulation/ interim-licences).

But 10 months after the Bill was passed, the New Zealand Government claimed the difficulties of introducing a new regulatory system had been underestimated and revoked existing interim licences. Forthcoming national elections and extensive (possibly organised) negative media may have contributed to the problems. However, the New Zealand Government is committed to restoring the regulatory system after the teething problems have been overcome. Many countries, including Australia, are following the New Zealand developments with great interest.

Initially only retired politicians, but now also serving senior politicians, are increasingly acknowledging that drug policy heavily reliant on law enforcement has comprehensively failed. ${ }^{6}$ During the decades in which the world relied on law enforcement to control drugs, the drug market expanded inexorably and drugs became more hazardous. ${ }^{7}$ In an environment of drug prohibition, more dangerous drugs often replace less dangerous drugs. ${ }^{8}$ Importantly, deaths, disease, crime, corruption and violence have increased alarmingly. ${ }^{7}$

Prime Minister Tony Abbott recently said "the war on drugs is fought as fiercely as we humanly can. It's not a war we will ever finally win; the war on drugs is a war you can lose ... but you've always got to fight it". ${ }^{\prime \prime}$ This is the first time an Australian prime minister has acknowledged the futility of the war on drugs. But Abbott did not explain why it was essential to continue a policy he has conceded not only cannot succeed but also can fail. Surely under these circumstances it is time to reconsider the options, realising that the inexorable law of supply and demand will always eventually overcome political intransigence. For too many decades, bad policy has been good politics.

The pace of drug law reform is starting to accelerate in many countries. Some European countries have started to redefine drugs as primarily a health and social issue, including the Netherlands in the 1970s, Switzerland in the 1990s and Portugal in 2001. Improved outcomes 
include reductions in crime, HIV infections, and deaths due to drug overdose. ${ }^{10}$ More recently, drug law reform has started in the Americas - the states of Colorado and Washington began taxing and regulating recreational cannabis this year, and there are plans to commence legalising cannabis in Uruguay within a few months. In the United States, public support for the war on drugs is falling. ${ }^{11}$

In 2016, the United Nations General Assembly will hold a Special Session on drug policy, brought forward from 2019 because of a perceived crisis in drug policy. The serenity prayer, often quoted by members of Alcoholics Anonymous, reminds us to have the courage to change what we can, the serenity to accept what cannot be changed and the wisdom to know the difference. It's time we had the serenity to accept that psychoactive drugs are part of our globalised and internet-connected world, and the courage to focus on reducing the harm that they cause. The threshold step required is redefining drugs as primarily a health and social phenomenon, to force governments to start funding health and social interventions properly.

Competing interests: No relevant disclosures.

Provenance: Commissioned; not externally peer reviewed.

1 European Monitoring Centre for Drugs and Drug Addiction, Europol. EU drug markets report: a strategic analysis. Lisbon: Europol, 2013. http://www.
emcdda.europa.eu/attachements.cfm/att_194336_EN_TD3112366ENC.pdf (accessed Aug 2014).

2 National Drug Strategy. Framework for a national response to new psychoactive substances. 7 Jul 2014. http://www.nationaldrugstrategy. gov.au/internet/drugstrategy/Publishing.nsf/content/fw-psychoactive (accessed Aug 2014).

3 New Zealand Parliament. Psychoactive Substances Bill - third reading. 11 Jul 2013. http://www.parliament.nz/en-nz/pb/debates/debates/50Han sD_20130711_00000044/psychoactive-substances-bill-\%E2\%80\%94third-reading (accessed Aug 2014).

4 Newberry J, Wodak A, Sellman D, Robinson G. New Zealand's regulation of new psychoactive substances. BMJ 2014; 348: g1534.

5 NZ Drug Foundation. Psychoactive Substances Act. Overview. http://www. drugfoundation.org.nz/psychoactive-substances-bill/history (accessed Aug 2014).

6 Global Commission on Drug Policy. War on drugs. Rio de Janeiro: GCDP, 2011 http://www.globalcommissionondrugs.org/wp-content/themes/gcdp_vl/ pdf/Global_Commission_Report_English.pdf (accessed Aug 2014).

7 Wodak A. The abject failure of drug prohibition. Aust N Z J Criminol 2014; 47: 190-201.

8 Westermeyer J. The pro-heroin effects of anti-opium laws in Asia. Arch Gen Psychiatry 1976; 33: 1135-1139.

9 Abbott A. Interview with Neil Mitchell, Radio 3AW [transcript]. 29 Apr 2014. https://www.pm.gov.au/media/2014-04-29/interview-neil-mitchell-radio3aw (accessed Aug 2014).

10 Douglas R, Wodak A, McDonald D. Alternatives to prohibition. Illicit drugs: how we can stop killing and criminalising young Australians. Canberra: Australia21, 2012. http://www.australia21.org.au/wp-content/ uploads/2013/11/ASIllicitDrugsR2.pdf (accessed Aug 2014).

11 Pew Research Center for the People and the Press. America's new drug policy landscape. 2 Apr 2014. http://www.people-press.org/2014/04/02/ americas-new-drug-policy-landscape (accessed Aug 2014). 